\title{
When Forests Take Over After Land Abandonment: Dissolved Organic Matter Response in Headwater Mountain Streams
}

\author{
Edurne Estévez ${ }^{1,2,3 *}$, Jose M. Álvarez-Martínez ${ }^{3}$, Thorsten Dittmar ${ }^{4,5}$, José Barquín ${ }^{3}$ and \\ Gabriel Singer ${ }^{1,6}$
}

${ }^{1}$ Department of Ecology, University of Innsbruck, Innsbruck, Austria, ${ }^{2}$ Laboratory of Stream Ecology, Department of Plant Biology and Ecology, University of the Basque Country, Leioa, Spain, ${ }^{3}$ IHCantabria - Instituto de Hidráulica Ambiental de la Universidad de Cantabria, Santander, Spain, ${ }^{4}$ Institute for Chemistry and Biology of the Marine Environment (ICBM), University of Oldenburg, Oldenburg, Germany, ${ }^{5} \mathrm{Helmholtz}$ Institute for Functional Marine Biodiversity (HIFMB), University of Oldenburg, Oldenburg, Germany, ${ }^{6}$ Department of Ecohydrology, Leibniz Institute of Freshwater Ecology and Inland Fisheries, Berlin, Germany

\section{OPEN ACCESS}

Edited by:

Anna Lupon,

Spanish National Research

Council, Spain

Reviewed by:

Alissa M. White,

University of Montana, United States

Maximilian Lau,

Technical University Bergakademie

Freiberg, Germany

*Correspondence:

Edurne Estévez

edurne.estevez-cano@uibk.ac.at

Specialty section:

This article was submitted to Water and Critical Zone,

a section of the journal

Frontiers in Water

Received: 18 March 2021

Accepted: 09 August 2021

Published: 09 September 2021

Citation:

Estévez E, Álvarez-Martínez JM, Dittmar T, Barquín J and Singer $G$ (2021) When Forests Take Over After

Land Abandonment: Dissolved

Organic Matter Response in Headwater Mountain Streams. Front. Water 3:682608.

doi: 10.3389/frwa.2021.682608
Dissolved organic matter (DOM) represents the largest pool of organic carbon in fluvial ecosystems. The majority of DOM in rivers is of terrigenous origin-making DOM composition highly dependent on vegetation cover and soil properties. While deforestation is still a worldwide anthropogenic phenomenon, current land cover change in temperate regions is often characterized by secondary succession processes following the abandonment of agricultural activities including grazing on pasturelands. This results in (secondary) forest expansion with a consequent, time-lagged transformation of soil properties. Predicting the time scale and spatial scale (i.e., location in the catchment: riparian vs. upslope areas) at which such land cover changes affect the terrestrial-aquatic carbon linkage and concomitantly alter properties of fluvial DOM as drivers of carbon cycling in freshwater ecosystems represents a new scientific challenge. In an attempt to identify potential legacy effects of land cover, i.e., reaction delays of fluvial DOM to changes in land cover, we here investigate the influence of specific current and historic (2 decade-old) land cover types on molecularly resolved fluvial DOM composition in headwater mountain streams. Our analysis is based on a scale-sensitive approach weighing in the distance of land cover (changes) to the stream and ultrahigh-resolution mass spectrometric analyses. Results identified the dominance of terrigenous DOM, with phenolic and polyphenolic sum formulae commonly associated to lignins and tannins, in all the studied streams. DOM properties mostly reflected present-day gradients of forest cover in the riparian area. In more forested catchments, DOM had on average higher molecular weight and a greater abundance of O-rich phenols and polyphenols but less aliphatics. Besides the modulation of the DOM source, our results also point to an important influence of photodegradation associated to variation in light exposition with riparian land cover in defining fluvial DOM properties. Despite expectations, we were unable to detect an effect of historic land cover on present-day DOM composition, at least at the investigated baseflow conditions, probably because of an overriding effect of current riparian vegetation.

Keywords: FT-ICR-MS, riparian vegetation, land cover legacy, photodegradation, pasture 


\section{INTRODUCTION}

Freshwater ecosystems, despite covering a relatively small percentage of Earth's surface, have an important role in the global carbon cycle as they transport, mineralize, and bury large amounts of organic carbon (Cole et al., 2007; Battin et al., 2008). Dissolved organic matter (DOM) represents the largest pool of organic carbon in most freshwater ecosystems (Wetzel, 2001) and its majority is of terrigenous origin (Raymond and Bauer, 2001; Jaffé et al., 2013). Specifically in headwater streams, DOM properties (i.e., quantity, composition, origin and reactivity) are strongly defined by catchment vegetation (Fiebig et al., 1990; Kaplan and Newbold, 1993; Mei et al., 2012), and likely sensitive to changes in land cover (e.g., Huang and Chen, 2009; Hulatt et al., 2014).

Mostly, land cover changes have been driven by vegetation-clearing, either to directly obtain natural resources like timber or to allow urbanization and expansion of agricultural activities including farming and grazing on pasturelands (Brandt et al., 1999; Geist and Lambin, 2002; Bürgi et al., 2004). These changes resulted in the transformation of more than $43 \%$ of the pre-industrial Earth's terrestrial surface by 1995 (Daily, 1995) and led to the large-scale loss of natural vegetation; 2.3 million $\mathrm{km}^{2}$ of forest were lost from 2000 to 2012 alone (Millennium Ecosystem Assessment, 2005). Notably, forest loss has exhibited unequal pace over time and among regions (Pinto-Correia and Kristensen, 2013). While at present deforestation is more accentuated in the tropics, where it has increased by $62 \%$ in the first decade of the millennium (Kim et al., 2015), it was historically more intensive in temperate regions. Indeed, Europe was the continent with the smallest fraction (30\%) of its original forests remaining by 1950 (Millennium Ecosystem Assessment, 2005). Since then, however, the expansion of land "use" for agriculture, cattle raising and urbanization has also been partly reversed worldwide with the abandonment of large areas (Munroe et al., 2013). This land abandonment allows secondary succession processes (Pugnaire et al., 2006), resulting in the expansion of shrublands and ultimately forests as shown by the increase of $800,000 \mathrm{~km}^{2}$ of forest cover worldwide between 2000 and 2012 (Hansen et al., 2013); and 300,000 km² in Europe between 1992 and 2015 (Palmero-Iniesta et al., 2020). This forest expansion is particularly relevant in mountain areas (MacDonald et al., 2000; Álvarez-Martínez et al., 2014), where it is indeed forecasted to continue in the future (e.g., Rounsevell et al., 2006; Pointereau et al., 2008).

Predicting effects of land cover change on carbon cycling is a primary objective of current research (Schindler and Hilborn, 2015). This requires, on the one hand, understanding how specific land cover types shape fluvial DOM properties. So far, studies have mostly focused on wetlands, peatlands and agricultural fields as dominant land cover types (Stanley et al., 2012), while research on how grassland or shrubland (i.e., grazing-impacted systems) influence DOM properties is relatively scarce. Nevertheless, recent studies (Seitzinger et al., 2002; Frost et al., 2006; Lu et al., 2014; Masese et al., 2017) show that DOM quantity (measured as concentration of dissolved organic carbon, DOC) and the relative proportion of in-stream produced, protein-like DOM of low molecular weight with high bioavailability increase with pasture coverage. In opposition, the aromatic DOM of high molecular weight becomes more important with increasingly woody vegetation and forests. Additionally, the relative importance of the mechanisms through which land cover shapes DOM properties, which include the modulation of terrestrial sources like vegetation and soils, instream DOM production or photodegradation, are still poorly understood. To unravel these mechanisms, it is essential to consider how the spatial scale modulates the influence of land cover on stream DOM properties, this is, the relative importance of riparian vegetation vs. the vegetation located in upslope areas. In-stream processes such as photodegradation or autochthonous DOM production, which highly depend on canopy cover on the stream, suggest a higher importance of the vegetation in the riparian zone. In contrast, the modulation of terrestrial DOM sources defines the catchment scale as appropriate from hydrological reasoning (i.e., all the DOM generated in the draining catchment can potentially reach the stream; e.g., Graeber et al., 2012; Heinz et al., 2015; Masese et al., 2017). Nevertheless, the importance of upslope areas to fluvial carbon exports is still highly debated (see Burrows et al., 2013; Hruška et al., 2014; Sawicka et al., 2016) and recent studies point to a proportionally higher contribution of the riparian areas, at least in boreal rivers (see the definition of Dominant Source Layer; Ledesma et al., 2018).

On the other hand, an evaluation of the effects of land cover change on current fluvial DOM properties may need to consider the effects of historical land cover patterns. Such land cover legacy effects (Bürgi et al., 2017) may arise because the transformation of soil OM characteristics occurs over longer time scales than the transformation of vegetation composition and coverage (Trumbore, 2009). So far, only one type of land cover change on DOM properties, clear-fell forest harvesting and the following natural recovery over $20-50$ years, has been rigorously assessed in US experimental forest facilities: Hubbard Brook Experimental Forest (Hobbie and Likens, 1973; Cawley et al., 2014), Coweeta Hydrologic Laboratory (Meyer and Tate, 1983; Yamashita et al., 2011) and J. Andrews Experimental Forest (Lee and Lajtha, 2016). Largely, these studies showed streams draining harvested forests to have overall lower DOC, specifically less aromatic, humic and fulvic-like compounds but more proteinaceous and microbially derived material. The only exception is an investigation of recent (1-19 year-old) clear-fell harvesting conducted by Burrows et al. (2013), which did not find a change in DOM source but showed contrasting changes in DOM composition after harvesting.

The primary objective of this study was to understand how land cover shapes DOM properties in headwater mountain streams. In the light of globally happening land abandonment and subsequent forest expansion, we specifically aimed to search for a land cover legacy effect on DOM properties (i.e., whether the historic land cover, grasslands for extensive cattle raising, is still detectable behind current land cover), analyzing the influence of current and historic land cover and the location in the catchment (i.e., riparian vs. entire catchment) on DOM quantity and composition. We hypothesized an overall dominance of terrigenous DOM with a greater proportion of 
A
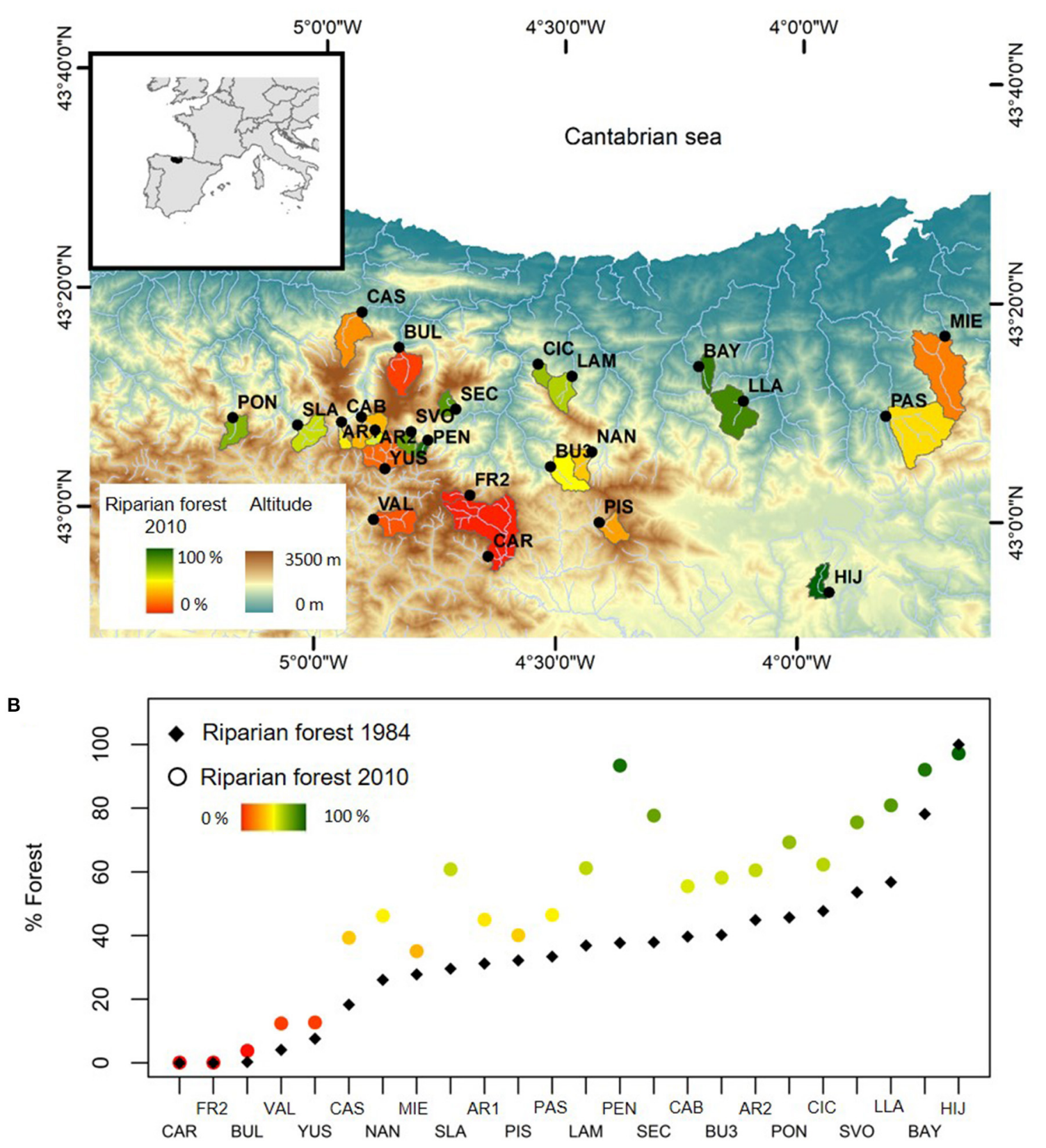

\section{Stream}

FIGURE 1 | (A) Map of the study area showing the location of the 24 streams and their catchments in the Cantabrian Mountains, Northern Spain. Catchments are colored according to current riparian forest cover. (B) Variation of riparian forest cover between 1984 (black diamonds) and 2009 (circles colored according to current riparian forest cover) in each of the studied streams. Stream codes correspond with Supplementary Material 1.

humic and aromatic DOM in more forested streams while streams draining more extensive grasslands were expected to be dominated by more recent and proteinaceous DOM. For catchments with a land abandonment history, we hypothesized slowly turning over soils to cause apparently "grasslandlike" DOM despite high current forest cover. Such a legacy effect may depend on the spatial scale of land cover (i.e., whether these effects are attributable to the riparian zone or 
upslope areas) and would inform about dominant processes driving fluvial DOM properties (e.g., relative importance of modulation of terrestrial sources, in-stream DOM production or photodegradation).

\section{MATERIALS AND METHODS}

\section{Study Area}

This study was conducted in the Cantabrian Mountains, a mountain range that spans more than $300 \mathrm{~km}$ across northern Spain, parallel to the Cantabrian Sea (Atlantic Ocean; Figure 1A). Here, more than 500 years ago, many forests were converted into grasslands for livestock grazing, which remained the most important economic activity in these mountainous rural areas (Barandiaran and Manterola, 2000) until a dramatic rural exodus over the last 50 years (Morán-Ordóñez et al., 2011; Álvarez-Martínez et al., 2016). The major decline in livestock grazing allowed secondary succession processes driving expansion of shrublands and forests (e.g., Poyatos et al., 2003; Álvarez-Martínez et al., 2014). Due to the quick recovery rates of some Atlantic forest species such as birches and beeches, younger forests with a grassland history may currently have a similar land cover type as old-growth forest despite evidently different landscape dynamics and ecological properties (Belmar et al., 2018; Figure 1B).

We characterized current and historic land cover in the study region and selected 24 streams along a gradient of current forest cover (Figure 1A, Supplementary Materials 1, 2). Unless current forest cover was $0 \%$, the various catchments experienced variable gains in forest cover over the assessed 26-year period. Land cover data was obtained from a supervised classification of remote sensing imagery (Landsat TM image of the study area for avoiding different sensors to be compared) from the years 2010 (current forest cover) and 1984 (historic forest cover) (Supplementary Material 1). We calculated the percentage of current and historic forest cover, as well as the corresponding change over the entire period. To test the influence of spatial scale, we estimated these variables on the scales of the entire catchment and the riparian area; the latter defined by a $200 \mathrm{~m}$ wide buffer along the river network upstream of the sampled site.

Current forest cover ranged from 0 to $79 \%$ in the catchment and from to 0 to $97 \%$ in the riparian area (Supplementary Material 1). Forest cover change varied from 0 to $28.9 \%$ at the catchment scale and from 2.8 to $55.7 \%$ in the riparian area. Catchment area varied from 4.9 to 86.8 $\mathrm{km}^{2}$ among streams, elevation from 188 to $1640 \mathrm{~m}$ a.s.l. and mean hill slope from 26.8 to $83.9 \%$. Water electric conductivity ranged from 51.45 to $307 \mu \mathrm{S} / \mathrm{cm}, \mathrm{pH}$ from 7 to 8.9 and total dissolved organic nitrogen from 0.2 to $415.1 \mu \mathrm{g} \mathrm{N} / \mathrm{L}$ (Figure 1B, Supplementary Material 2). All streams lacked sewage effluents or major pollution sources and agricultural and urban areas were scarce $(<1 \%$ of the catchment area). A more detailed description of the study area and streams is provided in Supplementary Material 2 and Estévez (2019).

\section{Sample Collection}

In September 2015, water samples were collected from each stream during baseflow conditions prior to the main leaf fall. This time was regarded as a potentially ideal moment to study legacy effects as the fraction of older soil OM in fluvial DOM would be enhanced, DOM variations related to hydrology minimized, and direct leaf litter inputs reduced. Water was on-line filtered through a double layer of pre-combusted $\left(450^{\circ} \mathrm{C}, 4 \mathrm{~h}\right)$ Whatman GF/F filters into acid-rinsed Nalgene PETG $2000 \mathrm{ml}$ bottles (Nalgene, Rochester, NY) in the field and kept cooled $\left(\sim 4{ }^{\circ} \mathrm{C}\right)$ and in darkness until processing in the laboratory. For the analysis of DOM composition by ultrahigh-resolution mass spectrometry, a volume between $888-5441 \mathrm{ml}$ was acidified to $\mathrm{pH} 2$ with 10 molar ultrapure $\mathrm{HCl}$ and $\mathrm{DOM}$ was extracted on a solid phase (Agilent Bond Elut $500 \mathrm{mg}$ PPL cartridges) and eluted with LCMS grade methanol (Dittmar et al., 2008). The volume of water extracted was computed from DOC data generated during a pilot campaign and aiming at a carbon-to-resin mass ratio of 400800. Additional $40 \mathrm{ml}$ samples were filtered (Whatman $\mathrm{GF} / \mathrm{F}$, double layer, pre-combusted) using disposable syringes into acidrinsed and pre-combusted $\left(450^{\circ} \mathrm{C}, 4 \mathrm{~h}\right)$ glass vials with PTFElined septa caps for spectroscopic and chromatographic DOM characterization (Supplementary Material 3).

\section{Ultrahigh-Resolution Mass Spectrometry}

For an in-depth characterization of DOM, we used ultrahighresolution Fourier-Transform Ion Cyclotron Mass Spectrometry (FT-ICR-MS). Leachates were adjusted to $15 \mathrm{ppm} \mathrm{C}$ in 1:1 ultrapure water/methanol before broadband mass spectrometry on a 15 Tesla Solarix FT-ICR-MS (Bruker Daltonics, Bremen, Germany) in electrospray ionization (ESI) negative mode (300 accumulated scans, $0.1 \mathrm{~s}$ ion accumulation time, $240 \mu \mathrm{L} / \mathrm{h}$ flow rate) searching for masses from 150 to $1,000 \mathrm{Da}$. After internal mass calibration, raw mass lists were exported for further data processing using in-house code in $\mathrm{R}$ (del Campo et al., 2019; Supplementary Material 4). Briefly, data below a method detection limit were deleted before alignment of peaks across samples. Peaks in fewer than five samples were not considered. Molecular formulae were assigned to $\mathrm{m} / \mathrm{z}$ values assuming singlecharged deprotonated molecular ions and $\mathrm{Cl}$-adducts for a maximum elemental combination of $\mathrm{C}_{100} \mathrm{H}_{250} \mathrm{O}_{80} \mathrm{~N}_{4} \mathrm{P}_{2} \mathrm{~S}_{2}$. To exclude unlikely formula assignments, we employed (i) a rigorous assessment of mass error and its partitioning into random and systematic components, (ii) a search for stable isotope confirmation by daughter peaks, and (iii) homologous series assessment (del Campo et al., 2019). The final dataset consisted of 3900 sum formulae covering on average $63 \%$ of total spectrum intensity. FT-ICR-MS data are graphically presented in van Krevelen plots, which show identified sum formulae in a space defined by $\mathrm{O}: \mathrm{C}$ (oxygen richness) and $\mathrm{H}: \mathrm{C}$ (saturation) ratios; plotting order was random to avoid bias created by systematic overplotting of thousands of compounds. To condense the rich mass-spectrometric information, we grouped formulae into 8 molecular groups (Supplementary Material 5), 7 of which are non-overlapping, based on elemental composition and derived structural information such as double bond equivalents and a computed aromaticity index (AI; Koch and Dittmar, 2006). We 
computed the total number of formulae, the total intensity and the intensity-weighted average molecular mass for all 8 molecular groups as well as the number of compounds with heteroatoms $(\mathrm{N}, \mathrm{S}$ or $\mathrm{P}$ ), the molecular richness (total number of differing formula) and evenness and Shannon diversity in each stream. As further responses, we computed the intensity-weighted average $\mathrm{AI}$, and the nominal oxidation state of carbon (NOSC; Wilson and Tfaily, 2018).

\section{Statistical Analysis}

First, a canonical analysis of principal coordinates (CAP; Anderson and Willis, 2003) based on Bray-Curtis dissimilarity was used to build a model explaining variation of DOM molecular composition with current and historic forest cover as well as the change (as increase 1984-2010) in forest cover both in the catchment and in the riparian area. Here, BrayCurtis dissimilarity was computed from relative intensities of the 3,900 compounds identified by FT-ICR-MS, that is, absolute intensities normalized by the total sum of intensities of a given spectrum. The constraining variables were subjected to a step-wise forward selection procedure using adjusted $R^{2}$ values (Blanchet et al., 2008) to develop a parsimonious model explaining DOM molecular composition (tests were done using 9,999 permutations). To further describe the main compositional gradients of DOM, we computed Spearman correlations between the significant CAP axes and the relative intensity, number of compounds and average molecular mass for the 8 molecular groups, FT-ICR-MS derived variables (i.e., molecular richness and evenness, Shannon diversity, number of compounds with heteroatoms and weighted average AI and NOSC). To confirm the correlation results, we additionally carried out two redundancy analyses (RDA) based on (i) the relative intensity, number of compounds and average molecular mass of the 8 molecular groups obtained from FT-ICR-MS data and (ii) variables obtained from additional spectroscopic and size-exclusion chromatographic analyses (see Supplementary Material 3 for a detailed description). A similar procedure as in the CAP analysis was followed, using the same constraining variables, a step-wise forward selection and Akaike information criterion to select the most parsimonious model. We further tested specifically for a legacy effect of historic land cover on DOM molecular composition by two approaches: (i) a conditioned CAP using the change in forest cover as a single predictor and the previously identified most important predictor, i.e., current riparian forest cover, as a condition; and (ii) a new CAP analysis performed including all predictors except for the current riparian forest cover. The latter was again subjected to a step-wise forward selection procedure using adjusted $\mathrm{R}^{2}$ values. All statistical analyses were performed in $\mathrm{R}$ (version 4.0.0, $\mathrm{R}$ Project for Statistical Computing, Vienna, Austria) using the packages vegan (Oksanen et al., 2017) and packfor (Dray et al., 2011).

\section{RESULTS}

The DOM pool was composed of a large number of compounds. In total, mass spectrometry detected 43,540 distinguishable peaks
TABLE 1 | Number and percentage of compounds derived from FT-ICR-MS across all the study streams.

\begin{tabular}{|c|c|c|c|}
\hline Molecular group & $\begin{array}{l}\text { Molecular } \\
\text { sub-group }\end{array}$ & $\begin{array}{l}\text { Number of } \\
\text { compounds }\end{array}$ & $\begin{array}{c}\text { Relative } \\
\text { percentage }\end{array}$ \\
\hline \multirow{2}{*}{$\begin{array}{l}\text { Combustion- } \\
\text { derived polycyclic } \\
\text { aromatics }\end{array}$} & $\begin{array}{l}\text { Without } \\
\text { heterotatoms }\end{array}$ & 159 & 4.08 \\
\hline & With heterotatoms & 31 & 0.79 \\
\hline \multirow[t]{2}{*}{ Polyphenols } & O-rich & 148 & 3.79 \\
\hline & O-poor & 441 & 11.31 \\
\hline \multirow{2}{*}{$\begin{array}{l}\text { Highly unsaturated } \\
\text { phenols }\end{array}$} & O-rich & 765 & 19.62 \\
\hline & O-poor & 1,770 & 45.38 \\
\hline \multirow[t]{2}{*}{ Aliphatics } & O-rich & 67 & 1.72 \\
\hline & O-poor & 279 & 7.15 \\
\hline \multirow[t]{2}{*}{ Fatty acids } & $\begin{array}{l}\text { Without } \\
\text { heterotatoms }\end{array}$ & 0 & 0.00 \\
\hline & With heterotatoms & 101 & 2.59 \\
\hline \multirow[t]{2}{*}{ Carbohydrates } & $\begin{array}{l}\text { Without } \\
\text { heteroatoms }\end{array}$ & 1 & 0.03 \\
\hline & With heteroatoms & 5 & 0.13 \\
\hline Proteins & & 133 & 3.41 \\
\hline $\begin{array}{l}\text { Carboxylic-rich } \\
\text { alicyclic } \\
\text { compounds }\end{array}$ & & 2,074 & 53.18 \\
\hline
\end{tabular}

across samples. These numbers include multiple peaks generated as part of isotope patterns from identical sum formulae. However, the applied method cannot distinguish among the many possible structural isomers and actual compound richness must therefore be notably higher. A total of 3,900 individually detected peaks (and their eventually existing isotope patterns) were assigned to molecular formulas, i.e., 9\% of all peaks detected, yet these covered on average $63 \%$ of a spectrum's summed peak intensities. Based on this set of assigned peaks, compound richness ranged from 3,326 to 3,714 in individual streams and $74 \%(2,891)$ of the compounds were ubiquitous. The majority of assigned compounds were phenolic (65\%), among which $45.4 \%$ were depleted in $\mathrm{O}(\mathrm{O} / \mathrm{C}<0.5)$ and $19.6 \%$ rich in $\mathrm{O}(\mathrm{O} / \mathrm{C}>0.5)$, followed by polyphenols (15.1\%) and aliphatic compounds (8.9\%). Combustion-derived polycyclic aromatics $(4.9 \%)$, proteins $(3.4 \%)$, fatty acids $(2.6 \%)$, and carbohydrates $(0.2 \%)$ were less numerous (Table 1). These molecular groups follow a non-overlapping definition. Occurrence of compounds with heteroatoms and CarboxylRich Alicyclic Molecules (CRAMs), which have potentially overlapping definitions, comprised 6.9 and $53.2 \%$ of a stream's compound richness, respectively. Patterns based on abundance of all these molecular groups (i.e., relative intensity) resembled those based on their counts: phenolic compounds were the most abundant $(78.6 \% \pm 2.8)$, especially phenols depleted in $\mathrm{O}(660.4 \pm 4.2)$, followed by polyphenols (11.9 \pm 1.6$)$, aliphatic compounds ( $4.4 \pm 1.7)$, combustion-derived polycyclic aromatics $(3.3 \pm 0.84)$, fatty acids $(1.0 \pm 0.21)$, proteins $(0.62$ $\pm 0.1)$ and carbohydrates $(0.04 \pm 0.02)$. On average, $69 \%$ 

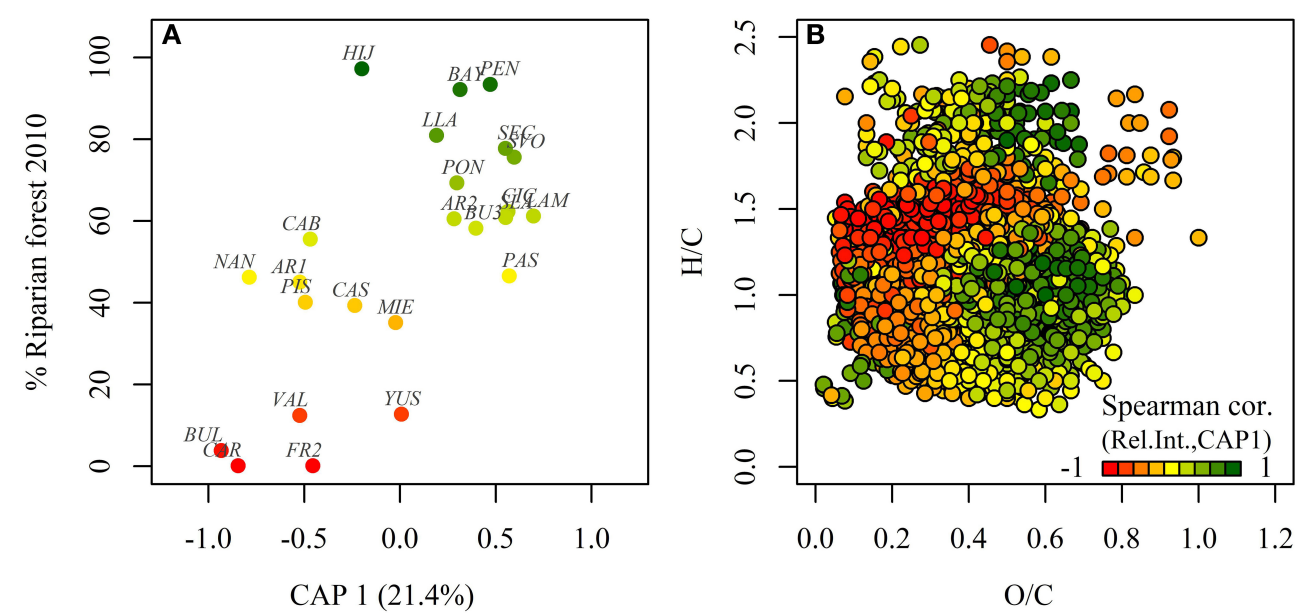

FIGURE 2 | Changes of DOM composition assessed by canonical analysis of principal coordinates (CAP) based on Bray-Curtis dissimilarity of DOM molecular composition are driven by a major constraint: current riparian forest cover, which defines the canonical axis 1 (CAP 1). (A) Relationship between CAP 1 and current riparian forest cover. The streams (stream codes are shown, Supplementary Material 1) are colored according to current riparian forest cover. (B) A Van Krevelen diagram shows the major changes in DOM composition associated with CAP 1. Point color indicates correlation of relative intensities of individual compounds with the canonical axis across all sampled streams. Red/green compounds decrease/increase in relative intensity with riparian forest cover. Compounds are plotted in random order.

TABLE 2 | Spearman correlations of molecular group variables derived from FT-ICR-MS (the relative intensity, number and weighted average mass of the compounds in each molecular group) with the first axis of the canonical analysis of principal coordinates (CAP) of DOM molecular composition (relative intensities of the 3,900 compounds) using the current riparian forest, as sole explanatory variable.

\begin{tabular}{|c|c|c|c|c|c|c|}
\hline \multirow[t]{2}{*}{ Molecular group } & \multicolumn{2}{|c|}{ Compound relative intensities } & \multicolumn{2}{|c|}{ Number of compounds } & \multicolumn{2}{|c|}{ Weighted average mass } \\
\hline & CAP 1 & $p$ & CAP 1 & $p$ & CAP 1 & $p$ \\
\hline $\begin{array}{l}\text { Combustion-derived polycyclic aromatics } \\
\text { without heterotatoms }\end{array}$ & 0.00 & 0.971 & 0.03 & 0.893 & 0.57 & 0.004 \\
\hline $\begin{array}{l}\text { Combustion-derived polycyclic aromatics with } \\
\text { heterotatoms }\end{array}$ & 0.20 & 0.353 & 0.67 & $<0.001$ & 0.74 & $<0.001$ \\
\hline O-rich polyphenols & 0.53 & 0.007 & 0.54 & 0.006 & 0.68 & $<0.001$ \\
\hline O-poor polyphenols & -0.31 & 0.147 & 0.46 & 0.024 & 0.76 & $<0.001$ \\
\hline O-rich highly unsaturated phenols & 0.93 & $<0.001$ & 0.57 & 0.004 & 0.85 & $<0.001$ \\
\hline O-poor highly unsaturated phenols & -0.73 & $<0.001$ & 0.34 & 0.109 & 0.79 & $<0.001$ \\
\hline O-rich aliphatics & -0.52 & 0.010 & -0.31 & 0.141 & 0.29 & 0.173 \\
\hline O-poor aliphatics & -0.91 & $<0.001$ & -0.61 & 0.002 & 0.20 & 0.338 \\
\hline Fatty acids with heterotatoms & 0.71 & $<0.001$ & 0.44 & 0.033 & -0.02 & 0.916 \\
\hline Carbohydrates with heteroatoms & -0.36 & 0.082 & -0.27 & 0.205 & 0.45 & 0.029 \\
\hline Proteins & 0.86 & $<0.001$ & 0.45 & 0.027 & 0.52 & 0.010 \\
\hline Carboxylic-rich alicyclic compounds & 0.57 & 0.004 & 0.53 & 0.008 & 0.83 & $<0.001$ \\
\hline
\end{tabular}

Significant $p$-values $(p<0.05)$ are highlighted in bold.

\pm 1.9 of a spectrum's assigned intensity could be attributed to CRAMs, which identifies compounds of this group as comparably abundant.

CAP results showed that current riparian forest cover alone $(p=0.002)$ explained $21.4 \%$ of the variability in DOM composition among streams (Figure 2A), pointing to a higher relevance of the riparian scale compared to the catchment scale. Spearman correlations of DOM compound relative intensities and CAP 1 (Figure 2B, Table 2) showed that CAP
1 was negatively related to the abundance of $\mathrm{O}$-poor highly unsaturated phenols and aliphatic compounds. In contrast, CAP 1 was positively associated with O-rich phenols and Orich polyphenols, fatty acids, proteins, and CRAMs (Figure 2B, Table 2). The number of compounds in each of the defined molecular groups followed the same pattern as their relative intensity, except highly unsaturated O-poor phenols and Orich aliphatics, which did not show a significant relationship with CAP 1 (Table 2). Further, combustion-derived polycyclic 
TABLE 3 | Spearman correlation of integrative variables from the FT-ICR-MS dataset with the first axis of the canonical analysis of principal coordinates (CAP) of DOM molecular composition (relative intensities of the 3,900 compounds) using its finally selected key environmental driver, the current riparian forest, as sole explanatory variable.

\begin{tabular}{llcc}
\hline Type of variable & Variable & CAP 1 & $\boldsymbol{p}$ \\
\hline FT-ICR-MS variables & Molecular richness & 0.41 & $\mathbf{0 . 0 4 7}$ \\
& Molecular evenness & 0.42 & $\mathbf{0 . 0 4 3}$ \\
& Shannon diversity & 0.57 & $\mathbf{0 . 0 0 4}$ \\
& Number of compounds & 0.60 & $\mathbf{0 . 0 0 2}$ \\
& with heteroatoms & & \\
NOSC & 0.82 & $\mathbf{0 . 0 0 1}$ \\
& Al & -0.54 & $\mathbf{0 . 0 0 6}$
\end{tabular}

Significant $p$-values $(p<0.05)$ are highlighted in bold.

aromatics with heterotatoms and O-poor polyphenols increased in number with CAP 1 . This variation of compounds resulted in a lower AI but greater NOSC with CAP 1, despite the limited variation among streams (0.33-0.35 and -0.3 to -0.24 , respectively; Table 3 ). Moreover, molecular richness and evenness, Shannon diversity and number of compounds with heteroatoms increased with CAP 1 (Table 3). CAP 1 was also positively related to the average mass of combustion-derived polycyclic aromatics, polyphenols, phenols, carbohydrates, proteins and CRAMs (Table 2).

RDA analysis of the molecular groups obtained from FT-ICR-MS data yielded similar results to those obtained already by the CAP, i.e., current riparian forest cover was the most important explanatory variable of the relative intensity, number of compounds and average molecular mass of the 8 molecular groups obtained from FT-ICR-MS data (Supplementary Material 6). However, the spectroscopic and size-exclusion chromatography barely yielded any significant results, probably because of a generally low variability of these parameters among streams (Supplementary Materials 7, 8).

The change in riparian forest cover from 1984 to 2010 had no significant effect on DOM composition. Forest cover change only explained an additional $7.8 \%(p=0.110)$ of compositional variation of DOM besides current riparian forest cover as a condition. In this case, neither CAP 1 nor change in riparian forest cover were significant ( $p=0.10$ and $p=0.11$, respectively). Moreover, when current riparian forest cover was not considered among the constraining variables, the most explanatory model included both the historic riparian forest cover and the riparian forest cover change ( $p=0.013$ and $p=0.004$, respectively), with both variables strongly and positively related to CAP 1, the only significant CAP axis ( $p=0.003$; Supplementary Material 8). Moreover, a strong Spearman correlation (cor. $=98.8, p<0.001$ ) between CAP 1 of both CAP analyses (i.e., current riparian forest cover and the combination of historic forest cover and forest cover change in the riparian area) indicated that the same turnover in DOM composition could be explained by either the current riparian forest cover or the combination of historic forest cover and forest cover change in the riparian area, further suggesting an absence of a land cover legacy effect (Supplementary Material 9).

\section{DISCUSSION}

Results showed the dominance of terrestrially derived DOM in all study streams and the variation of DOM properties with current land cover in the riparian zone, pointing to a strong influence of land cover in the immediate vicinity of the stream rather than at a catchment-wide scale. Notably, the studied land cover change had no effect on DOM properties, at least at the investigated baseflow conditions, probably because of an overriding effect of current riparian vegetation.

\section{DOM Composition Across Streams}

Most of the detected compounds, which were also the most abundant (in terms of intensity), were phenolic compounds and polyphenols with formulae commonly associated with lignins and tannins (Kim et al., 2003; Hertkorn et al., 2006; Sleighter and Hatcher, 2007). These compound categories are likely derived from complex biopolymers in plant tissues. This leads to a terrigenous origin of DOM, primarily from the leaching and decomposition of plant litter and soil organic matter. Carbohydrates, proteins and lipids, labile compounds most commonly produced in-stream or from fresh leaf litter (Marschner and Kalbitz, 2003; Koch and Dittmar, 2006; Sleighter and Hatcher, 2007, 2008), were scarce, both in number and abundance. This shows the dominance of high molecular weight, O-rich and aromatic DOM in all the studied streams. The dominance of terrestrially derived compounds and the limited availability of carbohydrates, proteins and lipids could be explained by the environmental factors that characterize mountain streams and the sampling period. Sampling for this study happened prior to main leaf fall in autumn, limiting direct vegetation inputs to senescent leaves of late summer. At the same time, low nutrient concentration, low water temperature and turbulent hydraulic conditions reduced algae development (Supplementary Material 2), which limited in-stream DOM production. Additionally, any in-stream produced DOM might have likely be rapidly consumed due to its greater bioavailability compared to the allochthonous inputs derived from terrigenous plant materials (Kritzberg et al., 2004; Toming et al., 2013).

\section{Variation of DOM Properties With Land Cover}

Current land cover in the riparian area was the strongest determinant of DOM composition in the study streams. Overall, more oxygenated terrestrially derived DOM with a higher molecular weight reached the streams in the most forested catchments. DOM in forest streams was further characterized by a lower proportion of aliphatics and O-poor phenols, but a higher proportion of O-rich phenols and polyphenols, and CRAMs. These results point to a strong influence of soil $\mathrm{OM}$ in shaping DOM properties. Polyphenols and polycyclic aromatics, compounds that are understood as being derived from decomposing vascular plants and combustion processes (Wickland et al., 2007; Yamashita et al., 2011), are considered to 
be more diagenetically altered products than O-poor phenols and highly unsaturated compounds (Aiken et al., 1985). This suggests that the DOM reaching the stream in forested catchments may originate from OM accumulated over time in organic horizons of catchment soils, probably enhanced by the greater OM production (i.e., litter input to top soil) of deciduous forests compared to grasslands (e.g., Kögel-Knabner, 2002). This would agree with previous studies that showed a greater influence from more recent soil $\mathrm{OM}$ in streams draining grasslands and a higher influence from decomposed soil-derived materials in forested streams (Lu et al., 2015; Seifert et al., 2016). More decomposed soil-derived OM is usually also characterized by a greater aromaticity (Lu et al., 2015). However, the AI, an index describing DOM aromaticity, was lower in the most forested streams. This may have been driven by the greater abundance of protein and fatty acids in these heavily forested streams, an unexpected result given that less decomposed soil OM and grassland vegetation were shown to be richer, among others, in proteins and fatty acids (e.g., Martens et al., 2004; Zocatelli et al., 2012). Thus, these signatures point to leachates from fresh leaf litter, which was demonstrated to be more abundant in forested areas (e.g., Estévez et al., 2019). Overall, these results indicate multiple DOM sources in forested catchments: organic soil horizons well-supplied with leaf litter deliver decomposed humic substances into the streams, while fresh leaf litter leaches few aromatic substances and more proteins and fatty acids. This multi-source DOM may have resulted in two disjunct populations of molecules (see van Krevelen diagram; Fig. 2b), and a greater richness and diversity of compounds in the most forested streams.

Despite the strong influence of current land cover on DOM properties, no legacy of historic land cover was detected. This absence of a land cover legacy opposes the results obtained by the few studies that analyzed land cover legacy effects on fluvial DOM properties. These studies (Hobbie and Likens, 1973; Meyer and Tate, 1983; Yamashita et al., 2011; Burrows et al., 2013; Cawley et al., 2014; Lee and Lajtha, 2016) showed that catchments where forest was harvested produced DOM with higher protein content and likely younger microbial origin. This seemed to be driven by changes in soil organic matter characteristics associated to differences in OM inputs, more specifically to differences in leaf litter production and quality, leaching kinetics, decomposition, and organic matter incorporation into forest soils (e.g., Park and Matzner, 2003; Kalbitz et al., 2007), rather than by variation of in-stream DOM production. Thus, even after decades of forest regrowth, which approximated vegetation with a composition similar to preharvest periods (although vegetation composition could also differ; e.g., Yamashita et al., 2011) or unharvested catchments, DOM in streams from formerly harvested catchments could still be distinguished, demonstrating a clear legacy effect at the time scale of decades. In the conceptual framework of this study, we also expected soil OM to be the strongest determinant of fluvial DOM. We thus hypothesized a land cover change legacy from the fact that soil development is slow and lags behind vegetation regrowth. Indeed, the time needed to achieve a similar soil OM composition in catchments previously used for agriculture as in catchments with old growth-forest, is most often longer than the 26-year time scale considered in our study (Poeplau et al., 2011). Also, we looked at a different trajectory of land cover change compared to previous studies. While in previous studies historic land cover (forest) experienced a dramatic step-change before gradual succession by regrowing forest for 20-50 years, in our study century-long use as pasture gradually gave way to forest regrowth for 26 years. We expected such a long land use for pasture to have led to a great soil loss via mineralization and erosion over decades, even centuries. In fact, we predicted even stronger land use legacy effects than the ones already reported, arguing that 2 decade-old secondary forest may be unable to produce typically forest-like fluvial DOM. This idea was based on the dominance of soil OM as a control on DOM and a rather slowly growing influence of the forest via leaf litter input to streams directly or to organic topsoil layers. The opposite seems to be the case in our study streams, as within a short time of several years the regrowth of secondary forest presumably led to a fast reactivation of the two DOM sources typical for forests: direct leaf litter inputs and organic matter deposition on topsoil layers.

We also rule out a second mechanism that could generate a legacy: the influence of former pasture land use on fluvial DOM, especially at short-term after land abandonment, due to the continuous leaching of nutrients that fuel in-stream DOM production. This would require either high stocks of nutrients or high mineralization rates in forest soils. We observed no evidence for higher nutrient concentrations in forest streams (e.g., total dissolved organic nitrogen ranged from 0.2 to 415.1 $\mu \mathrm{g} N / \mathrm{L}$ and Spearman correlation showed no relationship with current riparian forest cover; Spearman correlation $=-0.18 ; p$ $=0.393)$, periphyton biomass was low across all studied streams (periphyton chlorophyll a content ranged from 14 to $77 \mathrm{mg}$ Chla $/ \mathrm{m}^{2}$ across streams; Supplementary Material 2), and DOM also did not point to typical fresh, microbial signatures.

Besides evidently modulating sources of fluvial DOM, land cover can also affect its degradation pathways. The absence of forest in the riparian zone translates to less canopy cover of the stream (in this study, Spearman correlation between riparian forest cover and canopy cover $=0.79 ; p<0.001$ ). This facilitates DOM photodegradation, which could indeed be a major contributor to both the observed differences in DOM properties across streams and the absence of land cover legacy effects. Aromatic and high molecular weight DOM, like the lignin and tannin-like compounds that dominated in all the streams, was shown to be highly susceptible to photodegradation (Sulzberger and Durisch-Kaiser, 2009; Williams et al., 2010; Lu et al., 2015). The photodegradation of these compounds results in a generalized decline in molecular weight and oxidation, loss of carboxyl functionality and an increase of aliphatic compounds (Cory et al., 2010; Ward et al., 2014), similar to what we observed in this study. Moreover, photodegradation might have resulted in a chemical homogenization of DOM, thereby also explaining the presence of less diverse DOM in the least forested streams, as shown in previous studies (Dalzell et al., 2009; del Campo et al., 2019). Nevertheless, despite photodegradation being a highly plausible explanation for the obtained results, it needs to be considered that none of the 
parameters obtained from spectroscopic analyses, which often show a strong response to photodegradation (e.g., Hansen et al., 2016) varied among streams.

The photodegradation argument might also be supported by the fact that the influence of forest in our study is tied to the riparian zone. Land cover in a narrow area along the stream thus exerts most influence on DOM properties, in agreement with previous studies (Gergel et al., 1999; Hedges et al., 2000; Molinero and Burke, 2009; Ledesma et al., 2015). Reasons include riparian soils as a dominant DOM source, direct effects of vegetation through leaf litter inputs, and a degradation-driven effect through exposure to sunlight. Importantly, the latter two forces shaping DOM may override and mask any potential land use legacy effects. It needs to be considered that the land cover legacy effect on fluvial DOM properties could show seasonality (i.e., be tied to phases of the hydrological cycle) and be highly modulated by the vegetation leaf status and the intensity of solar radiation. Different flow paths, and consequently, soil OM pools, are activated with varying hydrology. During baseflow, water flows through deeper soil horizons whereas during high flows and heavy precipitation events, water flows through superficial and shallow soil horizons (Fellman et al., 2009; Sanderman et al., 2009). Shallower flow paths have been associated to the export of larger amounts of younger, plant-derived DOM (Kaiser et al., 1997; Butman et al., 2012) as OM from fresh plant materials is lost with soil depth (Fröberg et al., 2007; Malik and Gleixner, 2013). Thus, baseflow was selected as the ideal moment for studying potential legacy effects as the fraction of older soil OM in fluvial DOM with potentially higher discriminating power among current and historic land cover would be enhanced, while direct leaf litter inputs reduced. However, our study conducted at the end of summer was also characterized by a high solar radiation, which may have maximized photodegradation processes, likely masking any potential detection of land use legacy effects. Thus, for the moment, we can only conclude that without understanding how secondary succession processes affect DOM properties across seasons, it is not possible to ascertain the absence of a land cover legacy effect. Given that land abandonment is expected to increase in the near future and headwater streams represent the first link in the DOM transport continuum from terrigenous sources to the oceans, it is critical to gain a deeper understanding of how current and historic land cover and secondary succession processes affect fluvial DOM properties all year long, specifically in the face of hydrological dynamics.

\section{CONCLUSIONS}

Our study presents a comprehensive analysis of the detailed molecular composition of fluvial DOM in a gradient of forest cover. Moreover, to our knowledge, it represents the first study attempting an analysis of land use legacy effects related to secondary succession processes following the abandonment of grasslands historically used for extensive cattle raising. This study shows that mass spectrometry, an increasingly used tool believed to provide a deeper resolution of DOM composition (e.g., Wagner et al., 2019; Peter et al., 2020; Behnke et al., 2021; Kurek et al., 2021), may also be sensitive to subtle changes in DOM properties, thereby improving our ability to characterize fluvial DOM composition. Furthermore, the results demonstrate the relevance of current riparian forest cover in determining the composition of fluvial DOM. The absence of a soil-driven land cover legacy underlines the relevance of riparian vegetation type (grasslands-shrublands-forests) for defining fluvial DOM properties at baseflow likely through a combination of direct leaf input, DOM sourced from diagenetically young organic horizons and modulation of photodegradation.

\section{DATA AVAILABILITY STATEMENT}

Data available from the figshare repository at: https://doi.org/10. 6084/m9.figshare.15172734.v1.

\section{AUTHOR CONTRIBUTIONS}

EE and JB designed the experiment and GS supervised the experimental design. EE, JÁ-M, and TD collected, processed, and analyzed the data. EE, JB, and GS drafted the manuscript and JÁ-M and TD revised the manuscript. All authors contributed to the article and approved the submitted version.

\section{FUNDING}

This study was funded by the Spanish Ministry of Economy and Competitiveness as part of the RIVERLANDS (Ref: BIA2012-33572) and HYDRA (Ref: BIA2015-71197) projects. EE was supported by predoctoral and postdoctoral grants from the Basque Government.

\section{ACKNOWLEDGMENTS}

We acknowledge the Europe Peaks National Park and the Biodiversity Foundation of the Spanish Ministry of Agriculture, Food and Environment for their advice and project support. We thank Oscar Belmar and Barbara Behounek for help in the field and laboratory.

\section{SUPPLEMENTARY MATERIAL}

The Supplementary Material for this article can be found online at: https://www.frontiersin.org/articles/10.3389/frwa. 2021.682608/full\#supplementary-material 


\section{REFERENCES}

Aiken, G. R., McKnight, D. M., Wershaw, R. L., and MacCarthy, P. (1985). Humic Substances in Soil, Sediment and Water: Geochemistry, Isolation and Characterization. Hoboken, NJ: Wiley-Blackwell

Álvarez-Martínez, J., Gómez-Villar, A., and Lasanta, T. (2016). The use of goats grazing to restore pastures invaded by shrubs and avoid desertification: a preliminary case study in the spanish Cantabrian Mountains. L. Degrad. Dev. 27, 3-13. doi: 10.1002/ld r.2230

Álvarez-Martínez, J. M., Suárez-Seoane, S., Stoorvogel, J. J., and de Luis Calabuig, E. (2014). Influence of land use and climate on recent forest expansion: a case study in the Eurosiberian-Mediterranean limit of north-west Spain. J. Ecol. 102, 905-919. doi: 10.1111/1365-2745.12257

Anderson, M. J., and Willis, T. J. (2003). Canonical analysis of principal coordinates: a useful method of constrained ordination for ecology. Ecology 84, 511-525. doi: 10.1890/0012-9658(2003)084[0511:CAOPCA]2.0.CO;2

Barandiaran, J. M., and Manterola, A. (2000). Ganadería y Pastoreo en Vasconia. Bilbao.

Battin, T. J., Kaplan, L. A., Findlay, S., Hopkinson, C. S., Marti, E., Packman, A. I., et al. (2008). Biophysical controls on organic carbon fluxes in fluvial networks. Nat. Geosci. 1, 95-100. doi: 10.1038/ngeo101

Behnke, M. I., Stubbins, A., Fellman, J. B., Hood, E., Dittmar, T., and Spencer, R. G. M. (2021). Dissolved organic matter sources in glacierized watersheds delineated through compositional and carbon isotopic modeling. Limnol. Oceanogr. 66, 438-451. doi: 10.1002/lno.11615

Belmar, O., Barquín, J., Álvarez-Martínez, J. M., Peñas, F. J., and Del Jesus, M. (2018). The role of forest maturity in extreme hydrological events. Ecohydrology 11:e1947. doi: 10.1002/eco.1947

Blanchet, F. G., Legendre, P., and Borcard, D. (2008). Forward selection of explanatory variables. Ecology 89, 2623-2632. doi: 10.1890/07-0986.1

Brandt, J., Primdahl, J., and Reenberg, A. (1999). "Rural land-use and landscape dynamics-analysis of 'driving forces' in space and time," in Land-use Changes and Their Environmental Impact in Rural Areas in Europe, eds R. Krönert, J. Baudry, I. R. Bowler, and A. Reenberg (Unesco), 81-102.

Bürgi, M., Hersperger, A. M., and Schneeberger, N. (2004). Driving forces of landscape change - current and new directions. Landsc. Ecol. 19, 857-868. doi: $10.1007 / \mathrm{s} 10980-004-0245-8$

Bürgi, M., Östlund, L., and Mladenoff, D. J. (2017). Legacy effects of human land use: Ecosystems as time-lagged systems. Ecosystems 20, 94-103. doi: 10.1007/s10021-016-0051-6

Burrows, R. M., Fellman, J. B., Magierowski, R. H., and Barmuta, L. A. (2013). Allochthonous dissolved organic matter controls bacterial carbon production in old-growth and clearfelled headwater streams. Freshw. Sci. 32, 821-836. doi: $10.1899 / 12-163.1$

Butman, D., Raymond, P. A., Butler, K., and Aiken, G. (2012). Relationships between $\delta 14 \mathrm{C}$ and the molecular quality of dissolved organic carbon in rivers draining to the coast from the conterminous United States. Global Biogeochem. Cycles 26. doi: 10.1029/2012GB004361

Cawley, K. M., Campbell, J., Zwilling, M., and Jaffé, R. (2014). Evaluation of forest disturbance legacy effects on dissolved organic matter characteristics in streams at the Hubbard Brook Experimental Forest, New Hampshire. Aquat. Sci. 76, 611-622. doi: 10.1007/s00027-014-0358-3

Cole, J. J., Prairie, Y. T., Caraco, N. F., McDowell, W. H., Tranvik, L. J., Striegl, R. G., et al. (2007). Plumbing the global carbon cycle: Integrating inland waters into the terrestrial carbon budget. Ecosystems 10, 171-184. doi: 10.1007/s10021-006-9013-8

Cory, R. M., McNeill, K., Cotner, J. P., Amado, A., Purcell, J. M., and Marshall, A. G. (2010). Singlet oxygen in the coupled photochemical and biochemical oxidation of dissolved organic matter. Environ. Sci. Technol. 44, 3683-3689. doi: $10.1021 / \mathrm{es} 902989 \mathrm{y}$

Daily, G. C. (1995). Restoring value to the world's degraded lands. Science 269, 350-354. doi: 10.1126/science.269.5222.350

Dalzell, B. J., Minor, E. C., and Mopper, K. M. (2009). Photodegradation of estuarine dissolved organic matter: a multi-method assessment of DOM transformation. Org. Geochem. 40, 243-257. doi: 10.1016/j.orggeochem.2008.10.003 del Campo, R., Gómez, R., and Singer, G. (2019). Dry phase conditions prime wet-phase dissolved organic matter dynamics in intermittent rivers. Limnol. Oceanogr. 64, 1966-1979. doi: 10.1002/lno.11163

Dittmar, T., Koch, B., Hertkorn, N., and Kattner, G. (2008). A simple and efficient method for the solid-phase extraction of dissolved organic matter (SPE-DOM) from seawater. Limnol. Oceanogr. Methods 6, 230-235. doi: 10.4319/lom.2008.6.230

Dray, S., Legendre, P., and Blanchet, G. (2011). "packfor: forward selection with permutation [R package version 0.0-8/r100]," in Canoco 46.

Estévez, E. (2019). Effects of land cover change on mountain streams: a multi-level approach. Phd thesis. Available online at: https://www.educacion.gob.es/teseo/ mostrarRef.do?ref $=1741662$.

Estévez, E., Álvarez-Martínez, J. M., Álvarez-Cabria, M., Robinson, C. T., Battin, T. J., and Barquín, J. (2019). Catchment land cover influences macroinvertebrate food-web structure and energy flow pathways in mountain streams. Freshw. Biol. 64, 1557-1571. doi: 10.1111/fwb.13327

Fellman, J. B., Hood, E., Edwards, R. T., and D'Amore, D. V. (2009). Changes in the concentration, biodegradability, and fluorescent properties of dissolved organic matter during stormflows in coastal temperate watersheds. J. Geophys. Res. Biogeosci. 114:G01021. doi: 10.1029/2008JG0 00790

Fiebig, D. M., Lock, M. A., and Neal, C. (1990). Soil water in the riparian zone as a source of carbon for a headwater stream. J. Hydrol. 116, 217-237. doi: 10.1016/0022-1694(90)90124-G

Fröberg, M., Berggren Kleja, D., and Hagedorn, F. (2007). The contribution of fresh litter to dissolved organic carbon leached from a coniferous forest floor. Eur. J. Soil Sci. 58, 108-114. doi: 10.1111/j.1365-2389.2006.00812.x

Frost, P. C., Larson, J. H., Johnston, C. A., Young, K. C., Maurice, P. A., Lamberti, G. A., et al. (2006). Landscape predictors of stream dissolved organic matter concentration and physicochemistry in a Lake Superior river watershed. Aquat. Sci. 68, 40-51. doi: 10.1007/s00027-005-0802-5

Geist, H. J., and Lambin, E. F. (2002). Proximate causes and underlying driving forces of tropical deforestation. Bioscience 52, 143. doi: 10.1641/00063568(2002)052 [0143:PCAUDF]2.0.CO;2

Gergel, S. E., Turner, M. G., and Kratz, T. K. (1999). Dissolved organic carbon as an indicator of the scale of watershed influence on lakes and rivers. Ecol. Appl. 9, 1377-1390. doi: 10.1890/1051-0761(1999)009[1377:DOCAAI]2.0.CO;2

Graeber, D., Gelbrecht, J., Pusch, M. T., Anlanger, C., and von Schiller, D. (2012). Agriculture has changed the amount and composition of dissolved organic matter in Central European headwater streams. Sci. Total Environ. 438, 435-446. doi: 10.1016/j.scitotenv.2012.08.087

Hansen, A. M., Kraus, T. E. C., Pellerin, B. A., Fleck, J. A., Downing, B. D., and Bergamaschi, B. A. (2016). Optical properties of dissolved organic matter (DOM): Effects of biological and photolytic degradation. Limnol. Oceanogr. 61, 1015-1032. doi: 10.1002/lno.10270

Hansen, M. C., Potapov, P. V., Moore, R., Hancher, M., Turubanova, S. A., Tyukavina, A., et al. (2013). High-resolution global maps of 21 st-century forest cover change. Science 342, 850-853. doi: 10.1126/science. 1244693

Hedges, J. I., Mayorga, E., Tsamakis, E., McClain, M. E., Aufdenkampe, A., Quay, P., et al. (2000). Organic matter in Bolivian tributaries of the Amazon River: a comparison to the lower mainstream. Limnol. Oceanogr. 45, 1449-1466. doi: $10.4319 /$ lo.2000.45.7.1449

Heinz, M., Graeber, D., Zak, D., Zwirnmann, E., Gelbrecht, J., and Pusch, M. T. (2015). Comparison of organic matter composition in agricultural versus forest affected headwaters with special emphasis on organic nitrogen. Environ. Sci. Technol. 49, 2081-2090. doi: 10.1021/es505146h

Hertkorn, N., Benner, R., Frommberger, M., Schmitt-Kopplin, P., Witt, M., Kaiser, K., et al. (2006). Characterization of a major refractory component of marine dissolved organic matter. Geochim. Cosmochim. Acta 70, 2990-3010. doi: 10.1016/j.gca.2006.03.021

Hobbie, J. E., and Likens, G. E. (1973). Output of phosphorus, dissolved organic carbon, and fine particulate carbon from hubbard brook watersheds. Limnol. Oceanogr. 18, 734-742. doi: 10.4319/lo.1973.18.5.0734

Hruška, J., Krám, P., Moldan, F., Oulehle, F., Evans, C. D., Wright, R. F., et al. (2014). Changes in soil dissolved organic carbon affect reconstructed history and projected future trends in surface water acidification. Water. Air. Soil Pollut. 225, 1-13. doi: 10.1007/s11270-014-2015-9 
Huang, W., and Chen, R. F. (2009). Sources and transformations of chromophoric dissolved organic matter in the Neponset River Watershed. J. Geophys. Res. 114, G00F05. doi: 10.1029/2009JG000976

Hulatt, C. J., Kaartokallio, H., Asmala, E., Autio, R., Stedmon, C. A., Sonninen, E., et al. (2014). Bioavailability and radiocarbon age of fluvial dissolved organic matter (DOM) from a northern peatland-dominated catchment: effect of land-use change. Aquat. Sci. 76, 393-404. doi: 10.1007/s00027-014-0342-y

Jaffé, R., Ding, Y., Niggemann, J., Vähätalo, A. V., Stubbins, A., Spencer, R. G. M., et al. (2013). Global charcoal mobilization from soils via dissolution and riverine transport to the oceans. Science 340, 345-347. doi: $10.1126 /$ science. 1231476

Kaiser, K., Guggenberger, G., Haumaier, L., and Zech, W. (1997). Dissolved organic matter sorption on subsoils and minerals studied by 13C-NMR and DRIFT spectroscopy. Eur. J. Soil Sci. 48, 301-310. doi: 10.1111/j.1365-2389.1997.tb00550.x

Kalbitz, K., Meyer, A., Yang, R., and Gerstberger, P. (2007). Response of dissolved organic matter in the forest floor to long-term manipulation of litter and throughfall inputs. Biogeochemistry 86, 301-318. doi: $10.1007 /$ s10533-007-9161-8

Kaplan, L. A., and Newbold, J. D. (1993). "Biogeochemistry of dissolved organic carbon entering streams," in Aquatic Microbiology: An Ecological Approach (Blackwell Scientific Publications) 518.

Kim, D. H., Sexton, J. O., and Townshend, J. R. (2015). Accelerated deforestation in the humid tropics from the 1990s to the 2000s. Geophys. Res. Lett. 42, 3495-3501. doi: 10.1002/2014GL062777

Kim, S., Kramer, R. W., and Hatcher, P. G. (2003). Graphical method for analysis of ultrahigh-resolution broadband mass spectra of natural organic matter, the Van Krevelen Diagram. Anal. Chem. 75, 5336-5344. doi: 10.1021/ac0 $34415 p$

Koch, B. P., and Dittmar, T. (2006). From mass to structure: an aromaticity index for high-resolution mass data of natural organic matter. Rapid Commun. Mass Spectrom. 20, 926-932. doi: 10.1002/rcm.2386

Kögel-Knabner, I. (2002). The macromolecular organic composition of plant and microbial residues as inputs to soil organic matter. Soil Biol. Biochem. 34, 139-162. doi: 10.1016/S0038-0717(01)00158-4

Kritzberg, E. S., Cole, J. J., Pace, M. L., Granéli, W., and Bade, D. L. (2004). Autochthonous versus allochthonous carbon sources of bacteria: results from whole-lake 13C addition experiments. Limnol. Oceanogr. 49, 588-596. doi: $10.4319 /$ lo.2004.49.2.0588

Kurek, M. R., Stubbins, A., Drake, T. W., Moura, J. M. S., Holmes, R. M., Osterholz, H., et al. (2021). Drivers of organic molecular signatures in the Amazon River. Global Biogeochem. Cycles, e2021GB006938. doi: 10.1029/2021GB0 06938

Ledesma, J. L. J., Grabs, T., Bishop, K. H., Schiff, S. L., and Köhler, S. J. (2015). Potential for long-term transfer of dissolved organic carbon from riparian zones to streams in boreal catchments. Glob. Chang. Biol. 21, 2963-2979. doi: $10.1111 /$ gcb. 12872

Ledesma, J. L. J., Kothawala, D. N., Bastviken, P., Maehder, S., Grabs, T., and Futter, M. N. (2018). Stream dissolved organic matter composition reflects the riparian zone, not upslope soils in boreal forest headwaters. Water Resour. Res. 54, 3896-3912. doi: 10.1029/2017WR021793

Lee, B. S., and Lajtha, K. (2016). Hydrologic and forest management controls on dissolved organic matter characteristics in headwater streams of oldgrowth forests in the Oregon Cascades. For. Ecol. Manage. 380, 11-22. doi: 10.1016/j.foreco.2016.08.029

Lu, Y., Canuel, E. A., Bauer, J. E., and Chambers, R. M. (2014). Effects of watershed land use on sources and nutritional value of particulate organic matter in temperate headwater streams. Aquat. Sci. 76, 419-436. doi: 10.1007/s00027-014-0344-9

Lu, Y., Li, X., Mesfioui, R., Bauer, J. E., Chambers, R. M., Canuel, E. A., et al. (2015). Use of ESI-FTICR-ms to characterize dissolved organic matter in headwater streams draining forest-dominated and pasturedominated watersheds. PLOS ONE 10, 1-21. doi: 10.1371/journal.pone.01 45639

MacDonald, D., Crabtree, J. R., Wiesinger, G., Dax, T., Stamou, N., Fleury, P., et al. (2000). Agricultural abandonment in mountain areas of Europe: Environmental consequences and policy response. J. Environ. Manage. 59, 47-69. doi: 10.1006/jema.1999.0335
Malik, A., and Gleixner, G. (2013). Importance of microbial soil organic matter processing in dissolved organic carbon production. FEMS Microbiol. Ecol. 86, 139-148. doi: 10.1111/1574-6941.12182

Marschner, B., and Kalbitz, K. (2003). Controls of bioavailability and biodegradability of dissolved organic matter in soils. Geoderma 113, 211-235. doi: 10.1016/S0016-7061(02)00362-2

Martens, D. A., Reedy, T. E., and Lewis, D. T. (2004). Soil organic carbon content and composition of 130-year crop, pasture and forest land-use managements. Glob. Chang. Biol. 10, 65-78. doi: 10.1046/j.1529-8817.2003.00722.x

Masese, F. O., Salcedo-Borda, J. S., Gettel, G. M., Irvine, K., and McClain, M. E. (2017). Influence of catchment land use and seasonality on dissolved organic matter composition and ecosystem metabolism in headwater streams of a Kenyan river. Biogeochemistry 132, 1-22. doi: 10.1007/s10533-016-0269-6

Mei, Y., Hornberger, G. M., Kaplan, L. A., Newbold, J. D., and Aufdenkampe, A. K. (2012). Estimation of dissolved organic carbon contribution from hillslope soils to a headwater stream. Water Resour. Res. 48:W09514. doi: 10.1029/2011WR010815

Meyer, J. L., and Tate, C. M. (1983). The effects of watershed disturbance on dissolved organic carbon dynamics of a stream. Ecology 64, 33-44. doi: $10.2307 / 1937326$

Millennium Ecosystem Assessment (2005). Biodiversity Synthesis: Ecosystems and Human Well-Being. Washington, DC: Island press

Molinero, J., and Burke, R. A. (2009). Effects of land use on dissolved organic matter biogeochemistry in piedmont headwater streams of the Southeastern United States. Hydrobiologia 635, 289-308. doi: 10.1007/s10750-009-9921-7

Morán-Ordóñez, A., Suárez-Seoane, S., Calvo, L., and de Luis, E. (2011). Using predictive models as a spatially explicit support tool for managing cultural landscapes. Appl. Geogr. 31, 839-848. doi: 10.1016/j.apgeog.2010.09.002

Munroe, D. K., van Berkel, D. B., Verburg, P. H., and Olson, J. L. (2013). Alternative trajectories of land abandonment: causes, consequences and research challenges. Curr. Opin. Environ. Sustain. 5, 471-476. doi: $10.1016 /$ j.cosust.2013.06.010

Oksanen, J., Blanchet, F. G., Friendly, M., Kindt, R., Legendre, P., Mcglinn, D., et al. (2017). vegan: Community Ecology Package. R Packag. version 2.4-4, Available online at: https://CRAN.R-project.org/package=vegan.

Palmero-Iniesta, M., Espelta, J. M., Gordillo, J., and Pino, J. (2020). Changes in forest landscape patterns resulting from recent afforestation in Europe (1990-2012): defragmentation of pre-existing forest versus new patch proliferation. Ann. For. Sci. 77. doi: 10.1007/s13595-020-00946-0

Park, J. H., and Matzner, E. (2003). Controls on the release of dissolved organic carbon and nitrogen from a deciduous forest floor investigated by manipulations of aboveground litter inputs and water flux. Biogeochemistry 66, 265-286. doi: 10.1023/B:BIOG.0000005341.19412.7b

Peter, H., Singer, G., Ulseth, A. J., Dittmar, T., Prairie, Y. T., and Battin, T. J. (2020). Travel time and source variation explain the molecular transformation of dissolved organic matter in an alpine stream network. J. Geophys. Res. Biogeosci. 125:e2019JG005616. doi: 10.1029/2019JG005616

Pinto-Correia, T., and Kristensen, L. (2013). Linking research to practice: the landscape as the basis for integrating social and ecological perspectives of the rural. Landsc. Urban Plan. 120, 248-256. doi: 10.1016/j.landurbplan.2013.07.005

Poeplau, C., Don, A., Vesterdal, L., Leifeld, J., Van Wesemael, B., Schumacher, J., et al. (2011). Temporal dynamics of soil organic carbon after land-use change in the temperate zone-carbon response functions as a model approach. Glob. Chang. Biol. 17, 2415-2427. doi: 10.1111/j.1365-2486.2011.02408.x

Pointereau, P., Coulon, F., Girard, P., Lambotte, M., Stuczynski, T., Sánchez Ortega, V., et al. (2008). Analysis of Farmland Abandonment and the Extent and Location of Agricultural Areas That are Actually Abandoned or are in Risk to be Abandoned. Ispra: European Commission Joint Research Centre.

Poyatos, R., Latron, J., and Llorens, P. (2003). Land use and land cover change after agricultural abandonment. Mt. Res. Dev. 23, 362-368. doi: 10.1659/02764741(2003)023[0362:LUALCC]2.0.CO;2

Pugnaire, F. I., Luque, M. T., Armas, C., and Gutiérrez, L. (2006). Colonization processes in semi-arid Mediterranean old-fields. J. Arid Environ. 65, 591-603. doi: 10.1016/j.jaridenv.2005.10.002

Raymond, P. A., and Bauer, J. E. (2001). Riverine export of aged terrestrial organic matter to the North Atlantic Ocean. Nature 409, 497-500. doi: $10.1038 / 35054034$ 
Rounsevell, M. D. A., Reginster, I., Araújo, M. B., Carter, T. R., Dendoncker, N., Ewert, F., et al. (2006). A coherent set of future land use change scenarios for Europe. Agric. Ecosyst. Environ. 114, 57-68. doi: 10.1016/j.agee.2005.11.027

Sanderman, J., Lohse, K. A., Baldock, J. A., and Amundson, R. (2009). Linking soils and streams: sources and chemistry of dissolved organic matter in a small coastal watershed. Water Resour. Res. 45. doi: 10.1029/2008WR006977

Sawicka, K., Monteith, D. T., Vanguelova, E. I., Wade, A. J., and Clark, J. M. (2016). Fine-scale temporal characterization of trends in soil water dissolved organic carbon and potential drivers. Ecol. Indic. 68, 36-51. doi: 10.1016/j.ecolind.2015.12.028

Schindler, D. E., and Hilborn, R. (2015). Prediction, precaution, and policy under global change. Science 347, 953-954. doi: 10.1126/science.1261824

Seifert, A.-G., Roth, V.-N., Dittmar, T., Gleixner, G., Breuer, L., Houska, T., et al. (2016). Comparing molecular composition of dissolved organic matter in soil and stream water: Influence of land use and chemical characteristics. Sci. Total Environ. 571, 142-152. doi: 10.1016/j.scitotenv.2016.07.033

Seitzinger, S. P., Sanders, R. W., and Styles, R. (2002). Bioavailability of DON from natural and anthropogenic sources to estuarine plankton. Limnol. Oceanogr. 47, 353-366. doi: 10.4319/lo.2002.47.2.0353

Sleighter, R. L., and Hatcher, P. G. (2007). The application of electrospray ionization coupled to ultrahigh resolution mass spectrometry for the molecular characterization of natural organic matter. J. Mass Spectrom. 42, 559-574. doi: $10.1002 /$ jms. 1221

Sleighter, R. L., and Hatcher, P. G. (2008). Molecular characterization of dissolved organic matter (DOM) along a river to ocean transect of the lower Chesapeake Bay by ultrahigh resolution electrospray ionization Fourier transform ion cyclotron resonance mass spectrometry. Mar. Chem. 110, 140-152. doi: 10.1016/j.marchem.2008.04.008

Stanley, E. H., Powers, S. M., Lottig, N. R., Buffam, I., and Crawford, J. T. (2012). Contemporary changes in dissolved organic carbon (DOC) in humandominated rivers: Is there a role for DOC management? Freshw. Biol. 57, 26-42. doi: 10.1111/j.1365-2427.2011.02613.x

Sulzberger, B., and Durisch-Kaiser, E. (2009). Chemical characterization of dissolved organic matter (DOM): A prerequisite for understanding UVinduced changes of DOM absorption properties and bioavailability. Aquat. Sci. 71, 104-126. doi: 10.1007/s00027-008-8082-5

Toming, K., Tuvikene, L., Vilbaste, S., Agasild, H., Viik, M., Kisand, A., et al. (2013). Contributions of autochthonous and allochthonous sources to dissolved organic matter in a large, shallow, eutrophic lake with a highly calcareous catchment. Limnol. Oceanogr. 58, 1259-1270. doi: 10.4319/lo.2013.58. 4.1259

Trumbore, S. (2009). Radiocarbon and soil carbon dynamics. Annu. Rev. Earth Planet. Sci. 37, 47-66. doi: 10.1146/annurev.earth.36.031207.124300

Wagner, S., Fair, J. H., Matt, S., Hosen, J. D., Raymond, P., Saiers, J., et al. (2019). Molecular hysteresis: hydrologically driven changes in riverine dissolved organic matter chemistry during a storm event. J. Geophys. Res. Biogeosci. 124, 759-774. doi: 10.1029/2018JG004817

Ward, C. P., Sleighter, R. L., Hatcher, P. G., and Cory, R. M. (2014). Insights into the complete and partial photooxidation of black carbon in surface waters. Environ. Sci. Process. Impacts 16, 721-731. doi: 10.1039/C3EM00597F

Wetzel, R. G. (2001). Limnology: Lake and River Ecosystems. San Diego: Academic Press.

Wickland, K. P., Neff, J. C., and Aiken, G. R. (2007). Dissolved organic carbon in Alaskan boreal forest: sources, chemical characteristics, and biodegradability. Ecosystems 10, 1323-1340. doi: 10.1007/s10021-007-9101-4

Williams, C. J., Yamashita, Y., Wilson, H. F., Jaffé, R., and Xenopoulos, M. A. (2010). Unraveling the role of land use and microbial activity in shaping dissolved organic matter characteristics in stream ecosystems. Limnol. Oceanogr. 55, 1159-1171. doi: 10.4319/lo.2010.55.3.1159

Wilson, R. M., and Tfaily, M. M. (2018). Advanced molecular techniques provide new rigorous tools for characterizing organic matter quality in complex systems. J. Geophys. Res. Biogeosci. 123, 1790-1795. doi: 10.1029/2018JG004525

Yamashita, Y., Kloeppel, B. D., Knoepp, J., Zausen, G. L., and Jaffé, R. (2011). Effects of watershed history on dissolved organic matter characteristics in headwater streams. Ecosystems 14, 1110-1122. doi: 10.1007/s10021-011-9469-Z

Zocatelli, R., Lavrieux, M., Disnar, J. R., Le Milbeau, C., Jacob, J., and Bréheret, J. G. (2012). Free fatty acids in Lake Aydat catchment soils (French Massif Central): Sources, distributions and potential use as sediment biomarkers. J. Soils Sediments 12, 734-748. doi: 10.1007/s11368-012-0505-1

Conflict of Interest: The authors declare that the research was conducted in the absence of any commercial or financial relationships that could be construed as a potential conflict of interest.

The handling editor AL declared a past collaboration with one of the authors EE.

Publisher's Note: All claims expressed in this article are solely those of the authors and do not necessarily represent those of their affiliated organizations, or those of the publisher, the editors and the reviewers. Any product that may be evaluated in this article, or claim that may be made by its manufacturer, is not guaranteed or endorsed by the publisher.

Copyright (c) 2021 Estévez, Álvarez-Martínez, Dittmar, Barquín and Singer. This is an open-access article distributed under the terms of the Creative Commons Attribution License (CC BY). The use, distribution or reproduction in other forums is permitted, provided the original author(s) and the copyright owner(s) are credited and that the original publication in this journal is cited, in accordance with accepted academic practice. No use, distribution or reproduction is permitted which does not comply with these terms. 